\title{
SELECTED ISSUES OF OPERATIONAL USE OF RAIL DISC BRAKE
}

\author{
WOJCIECH SAWCZUK'
}

\section{Summary}

This article describes disc brakes, which in comparison to traditional block brakes are more often used in rail vehicles. Because of numerous advantages in comparison to a traditional air block brake, disc brakes, are more and more often utilized in passenger carriages and other railway vehicles. Stable and constant - in the whole speed range - coefficient of friction $\mu$, with the value: $\mu=0.35$ is a basic advantage of disc brake systems [7]. Attempt to increase train speed, triggers application of greater braking power i.e. braking systems rapidly absorbing and dispersing stored heat energy. For stimulation of cooling processes of friction set (brake disc and friction pad), discs with ventilation canals shaped by various vanes, are used. Thanks to such solution discs take off about $40 \%$ [4] of heat generated during braking. However, natural ventilation causes losses of energy for rotation of the disc during ride with switched off brakes, which is especially important for trains with little frequency of brakings and in cases when the profile of the track does not stimulate long-lasting braking.

This article presents selected issues of operational use of rail disc brake such us total resistance generated by brake disc divided into resistance of disc inertia as mass in rotational motion and resistance generated by disc's ventilator, and influence of blocked ventilation canals on braking process.

Keywords: disc brake, resistances of disc inertia in rotational motion, ventilation canals, disc temperature, coefficient of friction

\section{Introduction}

Operational use of disc brake showed that during braking from high speeds, heat load of braking system appears which as a consequence decreases efficiency of the brake and lengthens braking distance. To cool the disc, internal ventilation canals are used which take off certain amount of heat to the

Environment. However, discs with specifically shaped ventilation canals during rotation consume energy taken by the ventilator. What is more, condition of fast exchange of braking energy into heat, strictly depends on dirt inside ventilation canals and possibly on presence of broken stone or other foreign matters in disc's vane spaces. Concentration of heat energy on the brake disc influences deterioration of braking process, which

${ }^{1}$ Poznan University of Technology, Institute of Combustion Engines and Transport, Piotrowo 3 Street, 60-965 Poznan, e-mail: wojciech.sawczuk@put.poznan.pl, ph.: +48 616652023 
in critical case may lead to loss of braking power. During overhauls of braking system of train cars in accordance with operation-maintenance documentation [2], particular attention is paid to dirt and presence of foreign matters in disc's ventilation canals.

The purpose of this article is to present calculations of resistances of brake disc inertia as mass in rotational motion taking into account resistance generated by brake disc's ventilator [6] and to present results of stationary research of brake disc with closed vane space simulating presence of foreign matters in ventilation canals.

\section{Constructional characteristics of ventilated brake discs}

Requirements for disc braking systems, such as braking from high speed and realization bigger pressure of friction pads to the disc, are higher because in such conditions, natural cooling is not sufficient to give away heat generated during braking.

a)

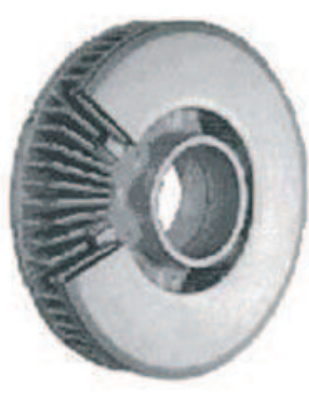

b)

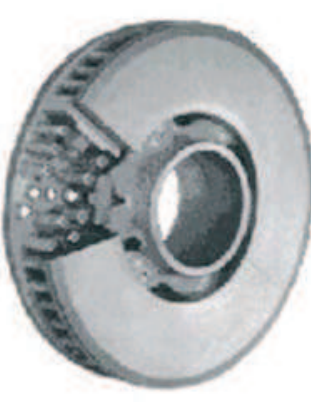

c)

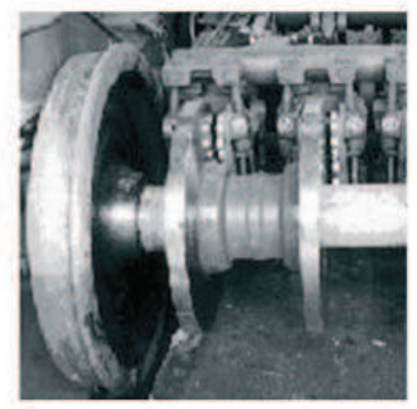

Fig. 1. Brake disc of rail vehicles: a) disc with ventilation vanes, b) disc with ventilation bars, c) solid disc (non-ventilated) [4].

As a consequence, deformation of brake disc appeared and this was connected with necessity to replace the disc before reaching acceptable wear of friction surface. To accelerate giving away heat accumulated during braking, discs with stimulated internal air flow started to be used. For this purpose spokewise arranged cooling vanes (Fig. la) or distance bars (Fig. 1b), are used.

Among ventilated discs, discs with ventilation vanes were the first ones to use for a large scale. Structure of such disc consists of two friction rings and ventilation vanes between the rings. From 60 to 100 vanes enable distribution of air, which flowing inside the disc takes away heat from inside of the disc to outside under the influence of centrifugal force. 
In canals between the vanes, increase of circumferential speed of the air occurs, which flowing inside the disc takes away heat generated during braking. Friction ring is made as monolith most often of grey cast iron or nodular cast iron and is connected with cast steel hub with 4 or 6 bolts (solution of company Knorr-Bremse), which at the same time enable axial thermal expansion of the disc against the hub, which is presented in figure 2 .

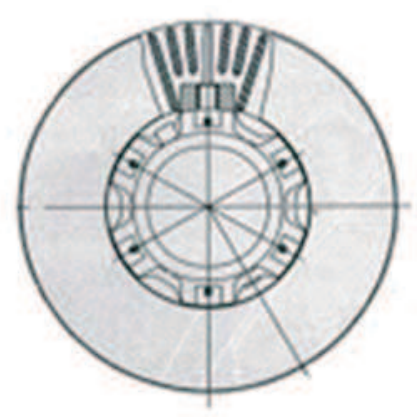

b)

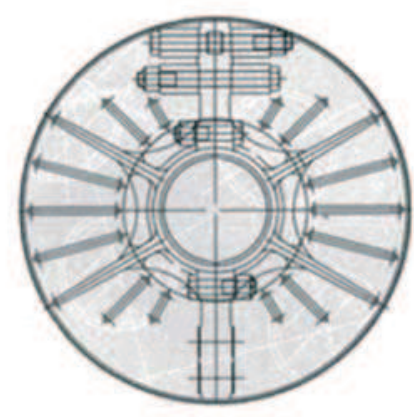

Fig. 2. Disc with ventilation vanes: a) monolithic friction ring, b) friction ring divided with brake hub into two [4].

A disc with ventilation bars is a more innovative solution. In comparison to discs with ventilation vanes, discs with ventilation bars show lower losses of energy resulting from stimulated ventilation without deteriorating the process of distributing heat energy generated during braking process. Such effect was obtained by replacing whirling vanes with densely arranged bars, by which, ventilated space was reduced by $1 / 3$. Dense arrangement of bars in the whole area inside the disc enables good heat conductivity and rotations of the disc take heat outside. Ingested air is decayed by the bars and through continuously changing direction of the flow, takes away accumulated heat energy more effectively.

Discs with ventilation bars are produced in sectional and monolithic form (common solution). It should be mentioned that elements joining discs take some part of internal area reducing intensity of cooling and easiness of rings replacement. 


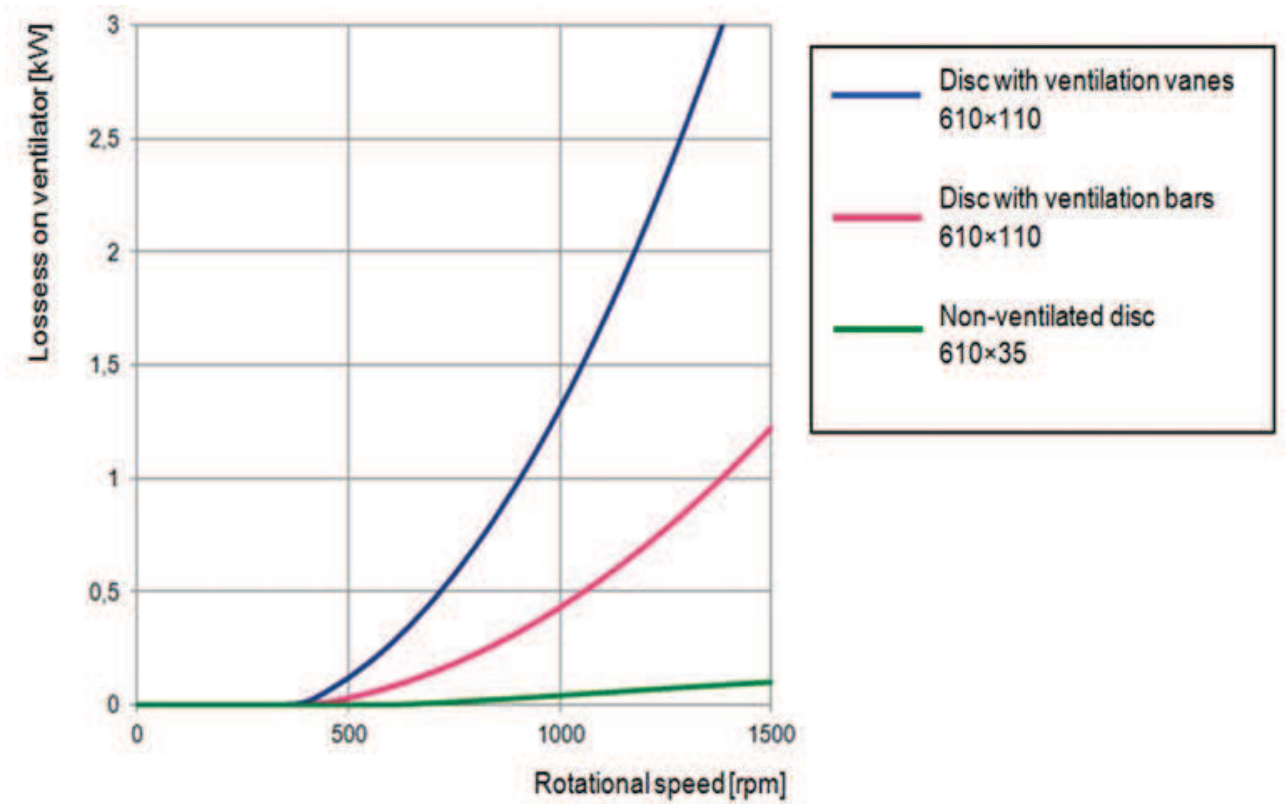

Fig. 3. Energy demand for ventilation process of brake discs [5].

For joining brake disc with the hub a solution of company Knorr-Bremse using 6 bolts is used. Disc constructed is such way is used in vehicles riding and speed of $160 \mathrm{~km} / \mathrm{h}$, as well as $200 \mathrm{~km} / \mathrm{h}$.

Tests [6] carried out on discs with ventilation bars and vanes showed that discs equipped with bars demand by $60 \%$ less energy because of natural ventilation than common discs with ventilation vanes. The tests also showed that in discs with ventilation bars it is possible to obtain by $3 \%$ higher average braking power and by even arrangement of bars in the whole disc area, braking heat is more intensively taken away to the environment. This means that despite weaker air pumping, in discs with ventilation bars, heat is taken away more effectively than in discs with ventilation vanes. Thanks to this, disc with ventilation bars is less sensitive to forming thermal cracks during sudden braking. Figure 3 presents comparative histories of the value of energy demand for pumping the air through the ventilator for discs with ventilation vanes and bars, and solid, non-ventilated disc in the function of rotational speed. 


\section{Method of assessing averaging power of energy dispersion by brake disc considered as solid body in rotational motion}

In discs with ventilation vanes and bars, besides energy losses on the ventilator, resistance of disc inertia as mass in rotational motion also occurs. To determine characteristics of power taken by the disc, data from table 1 should be used. Calculus of disc power of certain mass is presented on disc type 610×110 (diameter $\times$ width) for one rotational speed.

Table 1. Initial data to calculate resistance of brake disc inertia in rotational motion.

\begin{tabular}{|c|l|l|}
\hline $\begin{array}{c}\text { Ordinal } \\
\text { No. }\end{array}$ & Geometrical and thermodynamic value & $\begin{array}{l}\text { Designation } \\
\text { and values }\end{array}$ \\
\hline 1 & Mass of disc with ventilation vanes & $\mathrm{m}_{+}=123,2 \mathrm{~kg}$ \\
\hline 2 & Mass of disc with ventilation bars & $\mathrm{m}_{\mathrm{p}}=112,2 \mathrm{~kg}$ \\
\hline 3 & Mass of non-ventilated disc & $\mathrm{m}_{\mathrm{n}}=83,4 \mathrm{~kg}$ \\
\hline 4 & External diameter of ventilated and non-ventilated disc & $\mathrm{d}_{\mathrm{z}}=0,610 \mathrm{~m}$ \\
\hline 5 & Internal diameter of ventilated and non-ventilated disc & $\mathrm{d}_{\mathrm{w}}=0,193 \mathrm{~m}$ \\
\hline 6 & Cast iron density & $\rho \dot{z}=7200 \mathrm{~kg} / \mathrm{m}^{3}$ \\
\hline 7 & Steel density & $\rho \mathrm{s}=7850 \mathrm{~kg} / \mathrm{m}^{3}$ \\
\hline 8 & Linear acceleration & $\mathrm{a}=1,0 \mathrm{~m} / \mathrm{s}^{2}$ \\
\hline 9 & Rotational speed of the disc & $\mathrm{n}=1000 \mathrm{obr} / \mathrm{min}^{2}$ \\
\hline
\end{tabular}

Disc volume is calculated according to the following formula:

$$
V=\frac{m}{\rho}=\frac{123,2}{7200}=0,017\left[\mathrm{~m}^{3}\right],
$$

where: $m$ - mass of brake disc in $\mathrm{kg}, \rho$ - density of disc's material in $\mathrm{kg} / \mathrm{m}^{3}$.

Substitute thickness of working, annular part of the disc is determined from the following dependency:

$$
g_{z}=\frac{V}{\left(\frac{\pi \cdot d_{z}{ }^{2}}{4}-\frac{\pi \cdot d_{w}{ }^{2}}{4}\right)}=\frac{0,017}{\left(\frac{3,14 \cdot 0,61^{2}}{4}-\frac{3,14 \cdot 0,193^{2}}{4}\right)}=0,064[\mathrm{~m}]
$$

Moment of inertia of working ring is calculated according to the following formula:

$$
I=\frac{1}{2} \cdot m\left(\frac{d_{z}^{2}}{4}+\frac{d_{w}{ }^{2}}{4}\right)=\frac{1}{2} \cdot 123,2\left(\frac{0,61^{2}}{4}+\frac{0,193^{2}}{4}\right)=6,3\left[\mathrm{~kg} \cdot \mathrm{m}^{2}\right]
$$


Angular velocity of the disc, with assumed constant rotational speed $\mathrm{n}$ is determined from the following formula:

$$
\omega=\frac{d \varphi}{d t}=\frac{2 \cdot \pi \cdot n}{60}=\frac{2 \cdot 3,14 \cdot 1000}{60}=104,7\left[\frac{\mathrm{rad}}{\mathrm{s}}\right]
$$

Angular acceleration of the disc, with assumed constant value of vehicle's acceleration $a=1 \mathrm{~m} / \mathrm{s}^{2}$, is calculated from the following formula:

$$
\varepsilon=\frac{d \omega}{d t}=\frac{a}{\frac{d_{z}}{2}}=\frac{1}{\frac{0,61}{2}}=3,28\left[\frac{\mathrm{rad}}{\mathrm{s}^{2}}\right]
$$

Time of braking process can be assessed from the following dependency:

$$
t=\frac{\omega}{\varepsilon}=\frac{104,7}{3,28}=31,9[s]
$$

Initial, instantaneous kinetic energy of disc's ring is calculated from the following formula:

$$
E_{k}=\frac{I \cdot \omega^{2}}{2}=\frac{6,3 \cdot 104,7^{2}}{2}=34530,6[\mathrm{~J}]
$$

Averaging in time $t$, power of motion resistance of braking process is determined according to the following formula:

$$
N=\frac{d E}{d t}=\frac{E_{k}}{1000 \cdot t}=1,08[\mathrm{~kW}]
$$

This is calculation of one point of brake disc operation. To define further points of characteristics, identical procedures are used by substituting further values of rotational speed of brake disc. Presented calculus enables to calculate power used by discs of various structure with known mass, geometrical values and density of brake disc's material at constant angular acceleration $\times$

Figure 4 presents averaging history of resistance of disc inertia in rotational motion. Figure 5 presents the sum of resistances of disc inertia and resistance generated by brake disc's ventilator in rotational motion.

Figure 6 presents percentage of dispersed energy of disc in rotational motion against percentage of total energy of examined system. 

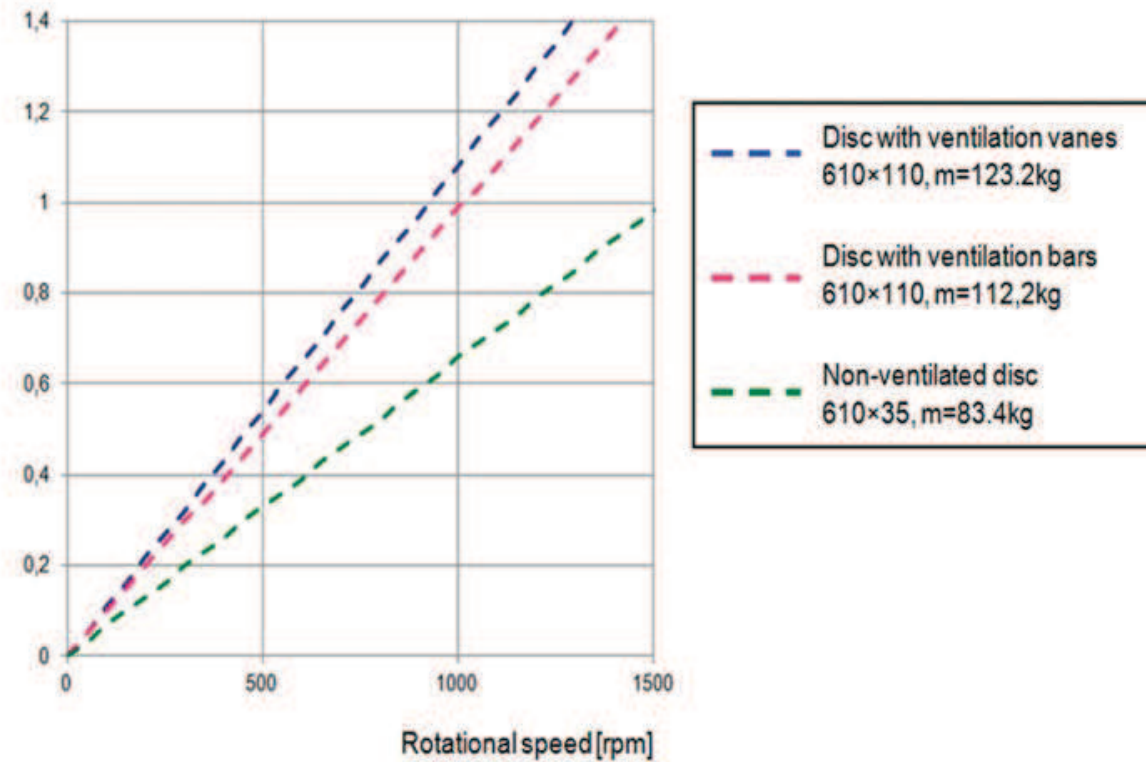

Fig. 4. History of averaging values of resistance power of brake disc motion in rotational motion in function of speed of this motion.

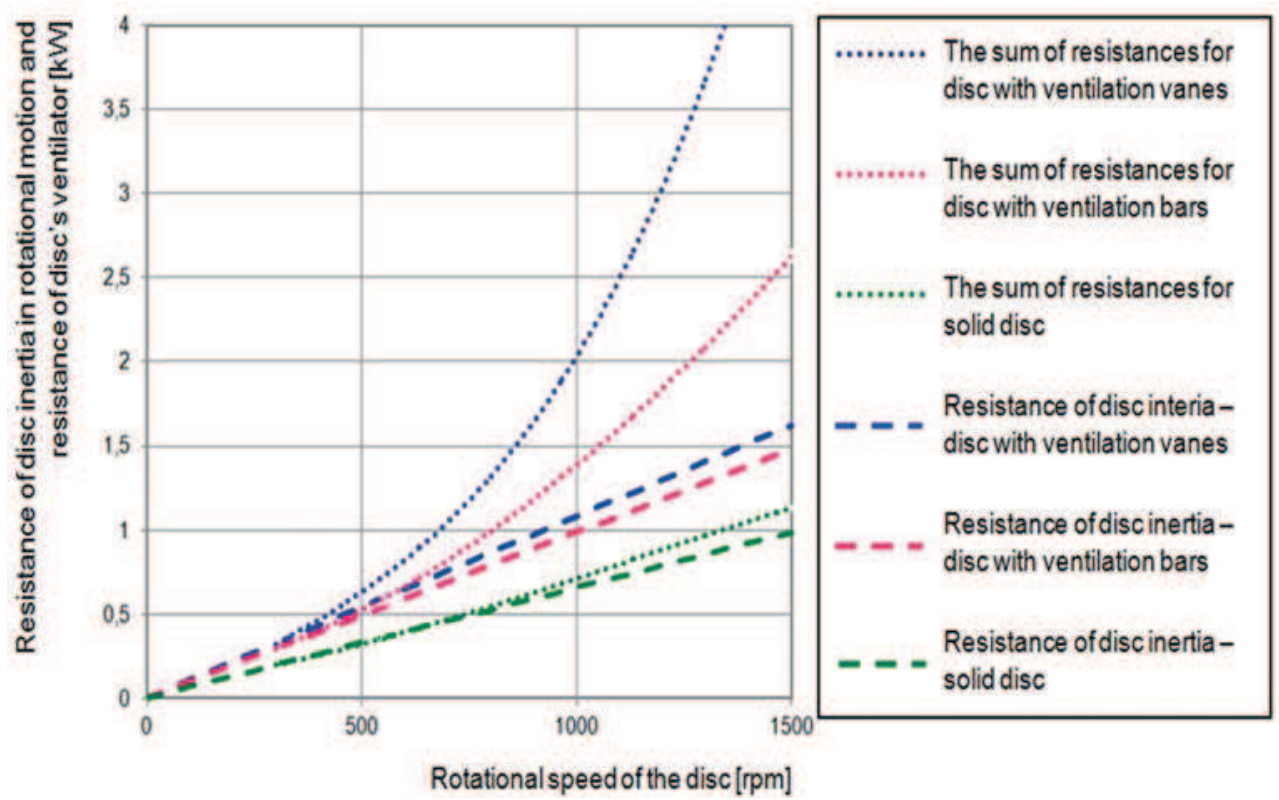

Fig. 5. The sum of resistances of brake disc in rotational motion (resistance of disc inertia in rotational motion and resistance generated by disc's ventilator). 


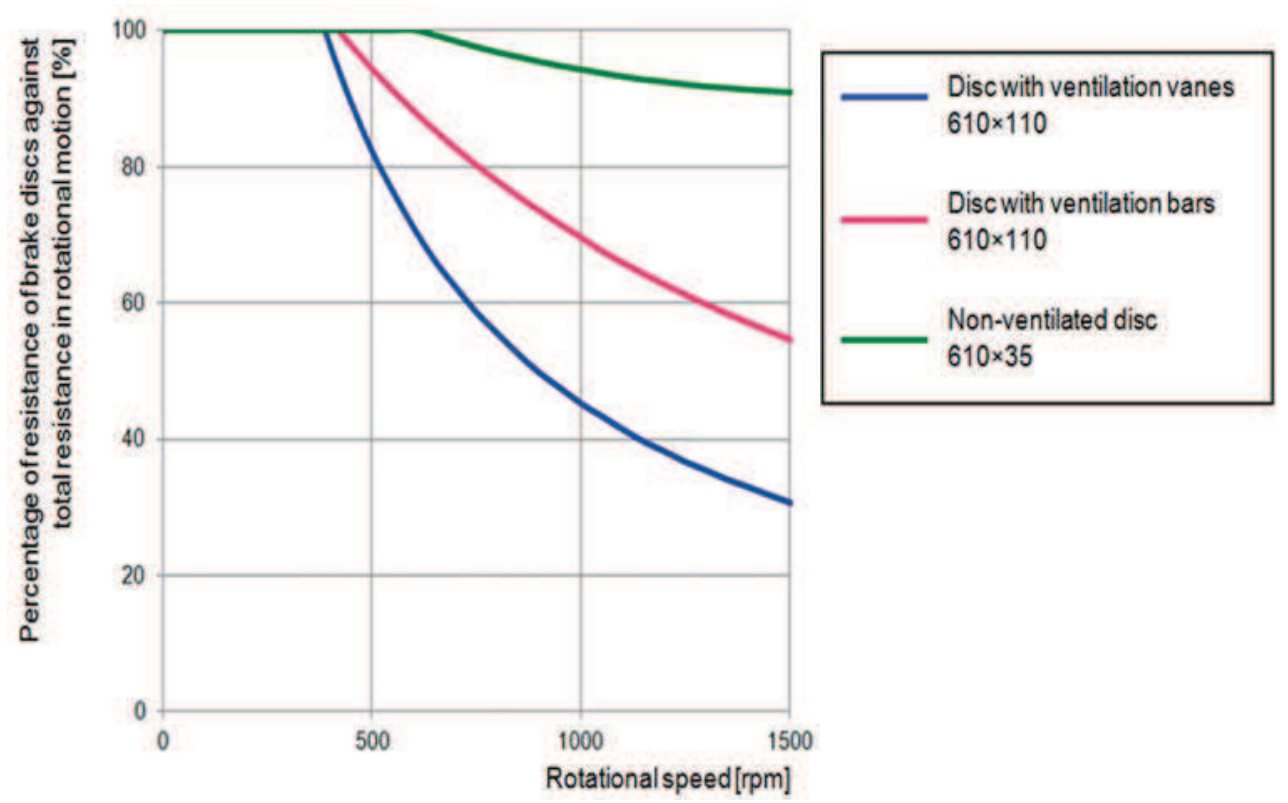

Fig. 6. Percentage of intertia resistance of brake disc against percentage of total resistance (resistance of disc inertia and resistance generated by brake disc).

\section{The research on railway disc brake with closed ventilation canals of brake disc}

\subsection{Methodology and object of research}

The tests were carried at an inertial station for testing rail vehicles brakes. A brake disc type 610x110 with ventilation vanes and a set of matched brake pads type 200 FR2OH.2 35 $\mathrm{mm}$ thick were the object of the test. Research program $\mathrm{C}$ (fast drive) was applied for the tests, according to [1] brakings were performed at speed of 120, 160 and $200 \mathrm{~km} / \mathrm{h}$, with pad pressure of $44 \mathrm{kN}$ to the disc and braking mass of 7,5 t per disc. Disc temperature in the whole range of braking time was registered by six thermocouples; three of them were mounted on two sides of the disc and placed every $120^{\circ}$ on three rays. The presence of foreign matters in the area between the vanes was simulated by placing a band clamp on ventilation vanes. The way how the ventilation areas were covered is presented in Fig. 7.

Before main tests were carried out a series of identification tests had been made on the disc with open ventilation canals, thanks to which undisturbed flow of cooling was provided. For each speed at the beginning of braking eight repetitions of braking were performed. 


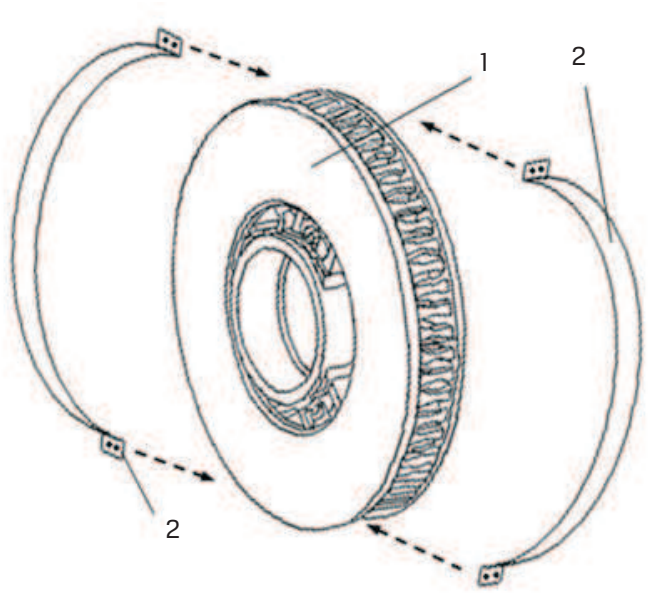

Fig. 7. Placing a band clamp on brake disc type 610×110: 1-brake disc, 2- right and left part of the band clamp.

\subsection{Analysis of tests results}

During tests the following parameters were measured: disc temperature at stoppage Fig. 8 , average friction coefficient Fig. 9 and time of disc cooling to $60^{\circ} \mathrm{C}$ Fig. 10. Disc cooling was realized by simulating a car ride at $100 \mathrm{~km} / \mathrm{h}$.

Brakings of a disc with covered ventilation vanes could lead to a change in the structure of the material as a result of strong thermal load. On the friction surface of the disc, overheating occurred in a form of two rings in the area of inner and outer diameter of the disc. Discoloration of the friction area was observed yet after six brakings (Fig. 11).

During brakings on the disc with covered vane area, on one of the thermocouples overflow of temporary disc temperature over $400{ }^{\circ} \mathrm{C}$ was registered and reached scope between $403 \div 417^{\circ} \mathrm{C}$. According to [1] brake discs of rail vehicle during brakings should not reach temporary temperature over $400{ }^{\circ} \mathrm{C}$, because this causes disc deformation and loss of required resistance and flexibility.

\section{Conclusion}

This article presents two aspects of operational use of rail disc brake. The first aspect refers to energy dispersed by brake disc's ventilator, the second aspect refers to influence of possibly existing ventilation canals on braking process.

Calculus presented in this article enables to assess averaging power of resistance of disc inertia as mass in rotational motion. Thanks to this, division of total disc's resistance into 


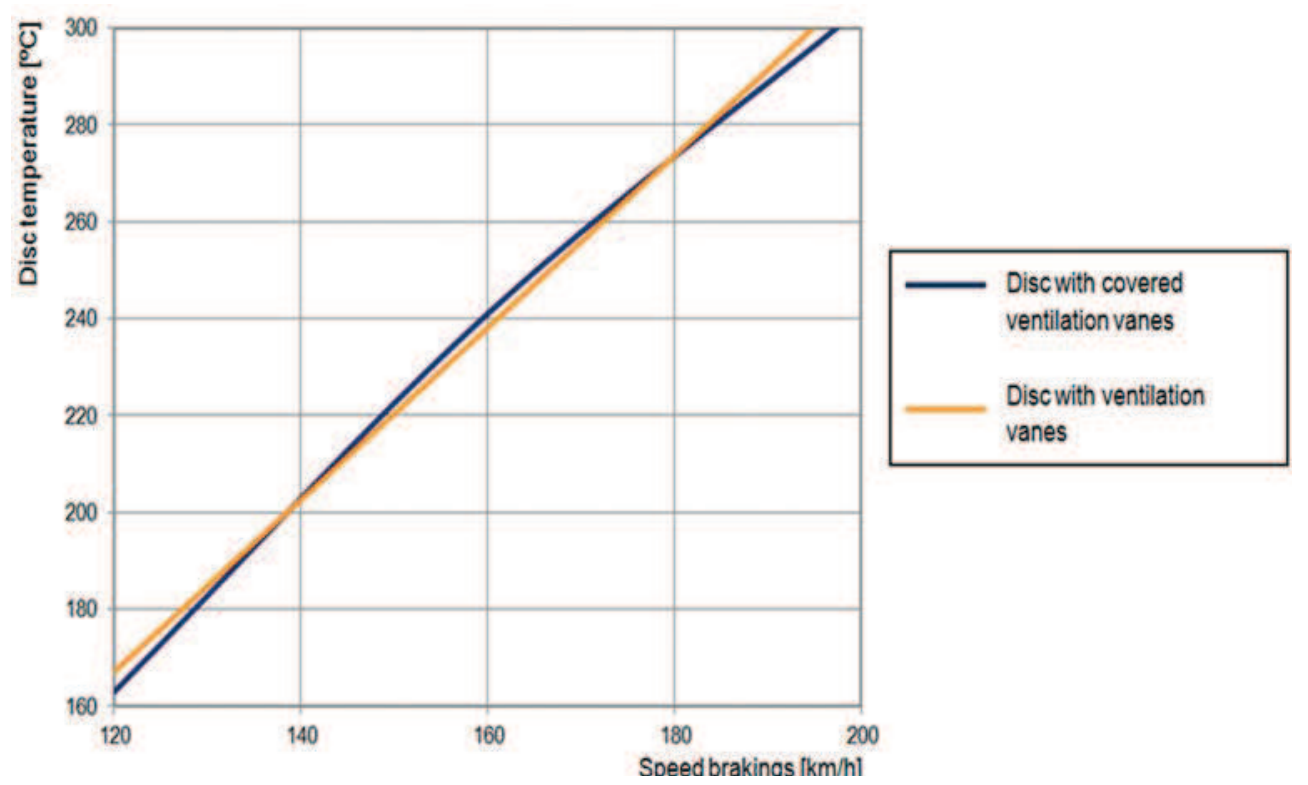

Fig. 8. Distribution of average temperature of brake disc type 610×110.

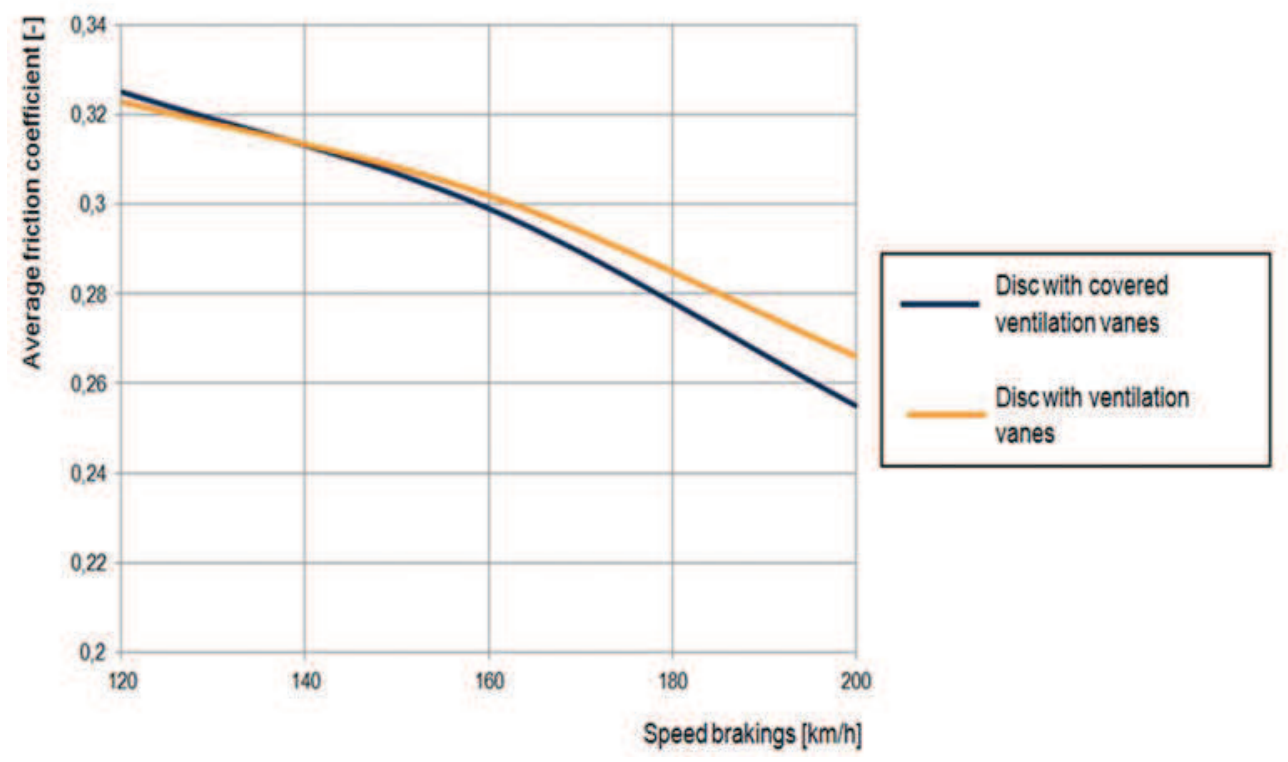

Fig. 9. History of average coefficient of friction. 


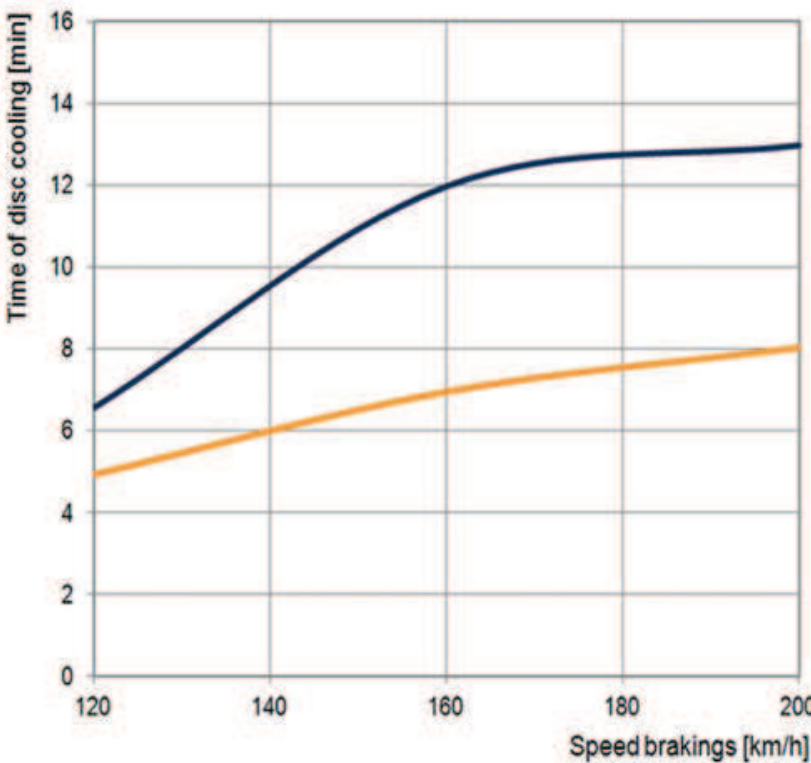

Disc with covered ventilationvanes

Disc with ventilation vanes

Fig. 10. History of cooling time of brake disc during simulated ride of train car at constant speed of $100 \mathrm{~km} / \mathrm{h}$ (disc rotational speed of 600 rpm).

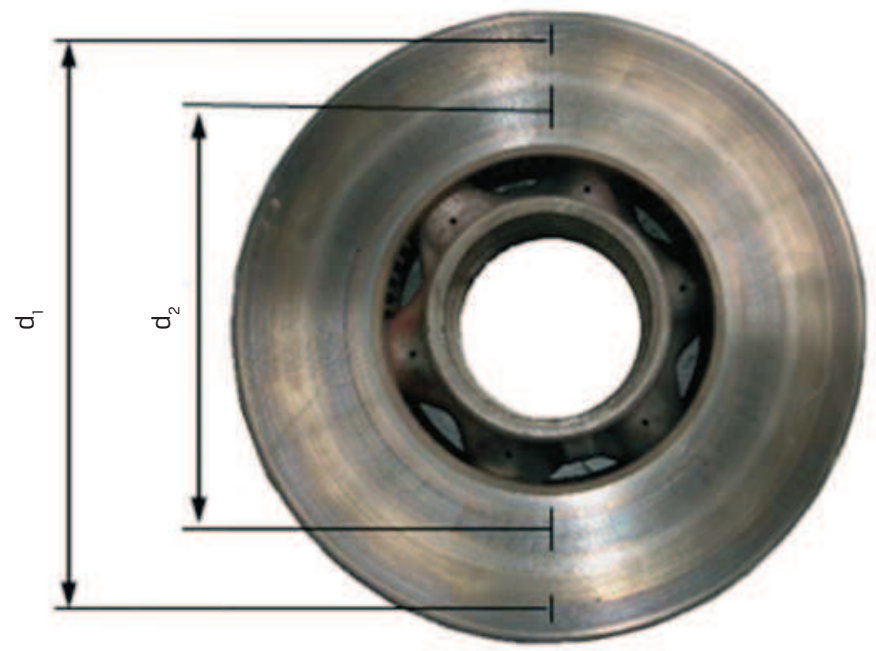

Fig. 11. The disc after series of brakings with covered ventilation vanes with visible surface overheating in a form of two rings of various diameters. 
resistance of disc inertia as mass in rotational motion and resistance of disc's ventilator during pumping air for the process of disc cooling, is possible.

Analyzing graphs presented in figure 5 it can be found out that despite the same dimension of discs (610×110), disc with ventilation bars produces by $9 \%$ lower resistance of disc inertia than disc with ventilation vanes in the whole range of rotational speed.

The biggest portion of resistance of disc inertia as mass in rotational motion occurs at $450 \mathrm{rpm}$ for ventilated disc and up to $600 \mathrm{rpm}$ for solid disc. Further increase of rotational speed increased losses on disc's ventilator. Percentage of losses stemming from rotation of disc of a certain mass against total losses decreases from $100 \%$ to $30 \%$ for disc with ventilation vanes and from $100 \%$ to $54 \%$ for disc with ventilation bars. In solid discs, mass losses constitute from $90 \%$ to $100 \%$ of total losses depending on rotational speed.

After stationary tests [5] it was found that covering the vane area and simulating the presence of foreign matters between vanes has no substantial influence on temperature measured at stoppage and the value of coefficient of friction in comparison to a disc with undisturbed ventilation. The changes in temperature and coefficient of friction are contained in statistical error. The change in disc temperature with open and closed vane area has not been noticed, which may stem from long period of breaking heat discharge into the environment against time of singular braking, what was described in [3].

However, covering vane has significant influence on cooling time of the disc after braking. A disc ventilated during car ride with a simulated speed of $100 \mathrm{~km} / \mathrm{h}$ cools by $25 \div 40 \%$ faster than a covered disc depending on speed at the beginning of braking.

\section{References}

[1] Kodeks UIC. Hamulec - Hamulec tarczowy i jego zastosowanie. Warunki dopuszczenia okładzin hamulcowych. Wydanie 6, listopad 2006

[2] Rail Consult Gesellschaft für Verkehrsberatung mbH. Wagon osobowy Z1 02, układ jezdny-tom2. Dokumentacja Techniczno-Ruchowa.

[3] SOROCHTE], M.: Kształtowanie jakości zespołu ciernego hamulca tarczowego. Przegląd Kolejowy 1/94.

[4] SAWCZUK, W., Zastosowanie płytek bimetalu w kolejowej tarczy hamulcowej z wentylującymi topatkami, XXVII Seminarium Kół Naukowych „Mechaników", Warszawa 24-25 kwietnia 2008r., s. 229.

[5] SAWCZUK, W., SZYMAŃSK, M. G.: The Research on Railway Disc Brake with Closed Ventilation Canals of the Brake Disc, Proc of $8^{\text {th }}$ European Conference of Young Research and Science Workers in Transport and Telecommunications TRANSCOM 2009, 22-24 June 2009, pp. 259-262.

[6] SIEMENS, G.: Auslegung und Leistungsgrenzen von Scheibenbremsen. „ZEV-Glas. Ann”. 112 (1988), nr. 4 April, pp. 139-143. 


\title{
WYBRANE PROBLEMY Z EKSPLOATACJI KOLEJOWEGO HAMULCA TARCZOWEGO
}

\author{
WOJCIECH SAWCZUK'
}

\section{Streszczenie}

Artykuł poświęcony jest hamulcom tarczowym, które w stosunku do tradycyjnego hamulca klockowego są częściej stosowane w pojazdach szynowych. Do podstawowych zalet tarczowych układów hamulcowych należy stały, niezmienny w całym zakresie prędkości współczynnik tarcia ślizgowego $\mu$, którego wartość wynosi $\mu=0,35$ [1]. Dążenie do podnoszenia prędkości pociągów wymusza stosowanie większych mocy hamowania a więc układów hamulcowych szybko przejmujących i rozpraszających nagromadzoną energię cieplną. Dla intensyfikacji procesów chłodzenia pary ciernej tarcza hamulcowaokładzina cierna stosuje się tarcze z kanałami wentylującymi ukształtowanymi poprzez różnego rodzaju łopatki. Dzięki temu tarcze te odprowadzają około 40\% [4] ciepła wytworzonego podczas hamowania. Wymuszona wentylacja powoduje jednak straty energii na ich obrót podczas jazdy przy wyłączonych hamulcach, co szczególnie istotne jest dla pociągów o małej częstotliwości hamowań oraz w przypadkach kiedy sam profil szlaku nie wymusza długotrwałego hamowania ruchowego.

Artykuł przedstawia wybrane zagadnienia z eksploatacji kolejowego hamulca tarczowego jak całkowity opór generowany przez tarczę hamulcową z podziałem na opór bezwładności masy tarczy w ruchu obrotowym i opór powodowany przez wentylator tarcz oraz wpływ zatkanych kanałów wentylacyjnych na proces hamowania.

Słowa kluczowe: hamulec tarczowy, opory bezwładności tarczy, kanały wentylacyjne, temperatura tarczy, współczynnik tarcia

\section{Wstęp}

Eksploatacja hamulca tarczowego pokazała, że przy hamowaniach z dużych prędkości, dochodzi do obciążenia cieplnego układu hamulcowego, co w konsekwencji zmniejsza sprawność hamulca i wydłuża drogę

hamowania. W celu schładzania tarcz stosuje się wewnętrzne kanały wentylacyjne, odprowadzające część ciepła do otoczenia. Jednakże tarcze ze specjalnie ukształtowanymi kanałami wentylacyjnymi w czasie obrotu są powodem zużycia energii pobieranej przez wentylator. Ponadto warunek szybkiej zamiany energii hamowania na ciepło jest ściśle uzależniony od zabrudzenia wewnętrznych kanałów wentylacyjnych i ew. obecności tłucznia lub innych obcych ciał w przestrzeniach łopatkowych tarczy. Koncentracja energii cieplnej na tarczy hamulcowej wpływa na pogorszenie procesu hamowania, co w skrajnym przypadku może doprowadzić do utraty siły hamowania. Podczas wykonywania

1 Politechnika Poznańska, Instytut Silników Spalinowych i Transportu, ul. Piotrowo 3, 60-965 Poznań,

e-mail: wojciech.sawczuk@put.poznan.pl, tel. (61) 665-2023 
przeglądów układu hamulcowego na wagonie zgodnie z dokumentacją techniczno ruchową [2], szczególną uwagę zwraca się na zabrudzenia i występowanie ciał obcych w kanatach wentylacyjnych tarczy.

Celem artykułu jest przedstawienie rachunku obliczania oporu bezwładności tarczy hamulcowej jako masa w ruchu obrotowym $z$ jednoczesnym uwzględnieniem oporu generowanego przez wentylator tarczy hamulcowej [6] oraz przedstawienie wyników badań stanowiskowych tarczy hamulcowej z zamkniętą przestrzenią łopatkową symulujących obecność ciał obcych w kanałach wentylacyjnych.

\section{Charakterystyka konstrukcyjna wentylowanych tarcz hamulcowych}

Wymagania stawiane tarczowym układom hamulcowym, jak hamowanie z dużych prędkości i realizacja większego docisku okładzin ciernych do tarczy spowodowało, że naturalne ich chłodzenie jest niewystarczające w oddawaniu nagromadzonego ciepła, powstałego w czasie hamowania.

a)

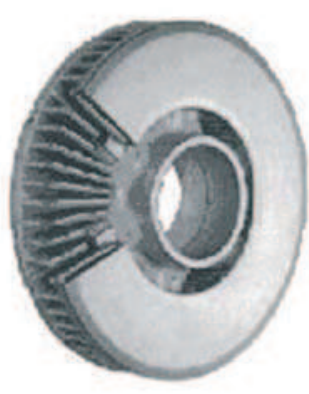

b)

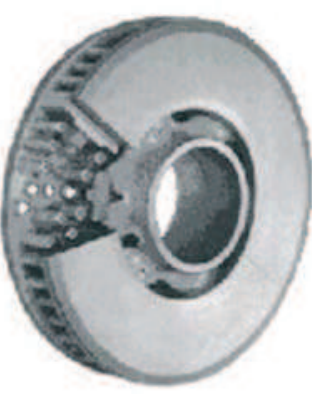

C)

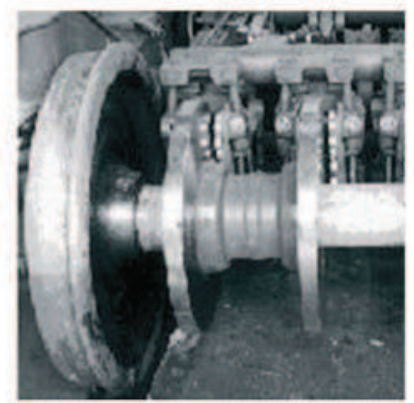

Rys. 1. Tarcze hamulcowe pojazdów szynowych: a) tarcza z wentylującymi łopatkami, b) tarcza z wentylującymi prętami, c) tarcza pełna (niewentylowana) [4].

W konsekwencji dochodziło do odkształcenia tarczy hamulcowej, co wiązało się z koniecznością jej wymiany przed osiągnięciem dopuszczalnego zużycia powierzchni ciernej. W celu przyspieszenia oddawania nagromadzonego ciepła podczas hamowania zaczęto stosować tarcze z wymuszonym wewnętrznym przepływem powietrza. Stosuje się przy tym promieniście rozłożone łopatki chłodzące (rys.la) lub pręty dystansowe (rys.1b).

Spośród tarcz wentylowanych jako pierwsze na szeroką skalę były stosowane tarcze z wentylującymi łopatkami. Konstrukcja takiej tarczy składa się z dwóch pierścieni ciernych, pomiędzy którymi znajdują się łopatki wentylujące. Łopatki w liczbie od 60 do 100 
sztuk umożliwiają "transportowanie" powietrza z części środkowej tarczy na zewnątrz pod wpływem siły odśrodkowej.

W kanałach między łopatkami następuje przyrost prędkości obwodowej powietrza, które przepływając wewnątrz tarczy „odbiera" ciepło powstałe w czasie hamowania. Pierścień cierny wykonany jako monolit najczęściej z żeliwa szarego lub sferoidalnego, jest połączony ze staliwną piastą za pomocą 4 lub 6 sworzni (rozwiązanie firmy Knorr-Bremse), które jednocześnie umożliwiają osiową rozszerzalność cieplną tarczy względem piasty, co przedstawia rysunek 2.

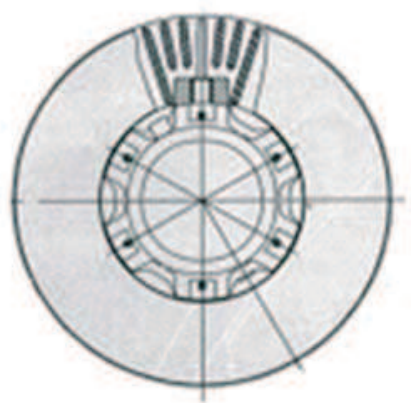

b)

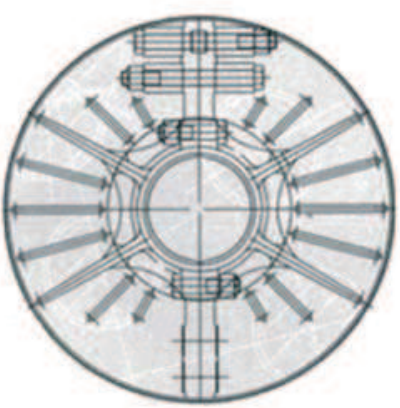

Rys. 2. Tarcza z wentylującymi łopatkami: a) pierścień cierny w postaci monolitycznej, b) pierścień cierny dzielony wraz z piastą hamulcową [4].

Rozwiązaniem nowszym od tarcz z wentylowymi łopatkami są tarcze z wentylującymi prętami. W odróżnieniu od tarcz z łopatkami wykazują one mniejsze straty energii w wyniku wymuszonej wentylacji bez pogorszenia procesu rozpraszania energii cieplnej powstałej w procesie hamowania. Taki efekt uzyskano zastępując wirujące łopatki gęsto rozmieszczonymi prętami (rys.1b), przez co przestrzeń wentylowana została zmniejszona o 1/3. Gęste rozmieszczenie prętów na całej powierzchni wewnątrz tarczy umożliwia dobre przewodzenie cieplne a ogólnie pojmowany ruch tarczy powoduje odprowadzenie ciepła na zewnątrz. Zassane powietrze jest rozbijane przez pręty i ciągle zmieniając kierunki przepływu efektywniej odbiera nagromadzoną energię cieplną w stosunku do tarczy z wentylującymi łopatkami.

Tarcze z wentylowanymi prętami występują również w postaci dzielonej lub w postaci monolitycznej (rozwiązanie klasyczne). Należy nadmienić, że elementy łączące tarcze zabierają część przestrzeni wewnętrznej zmniejszając tym samym intensywność chłodzenia kosztem możliwości łatwej i szybkiej wymiany pierścienia na nowy. 


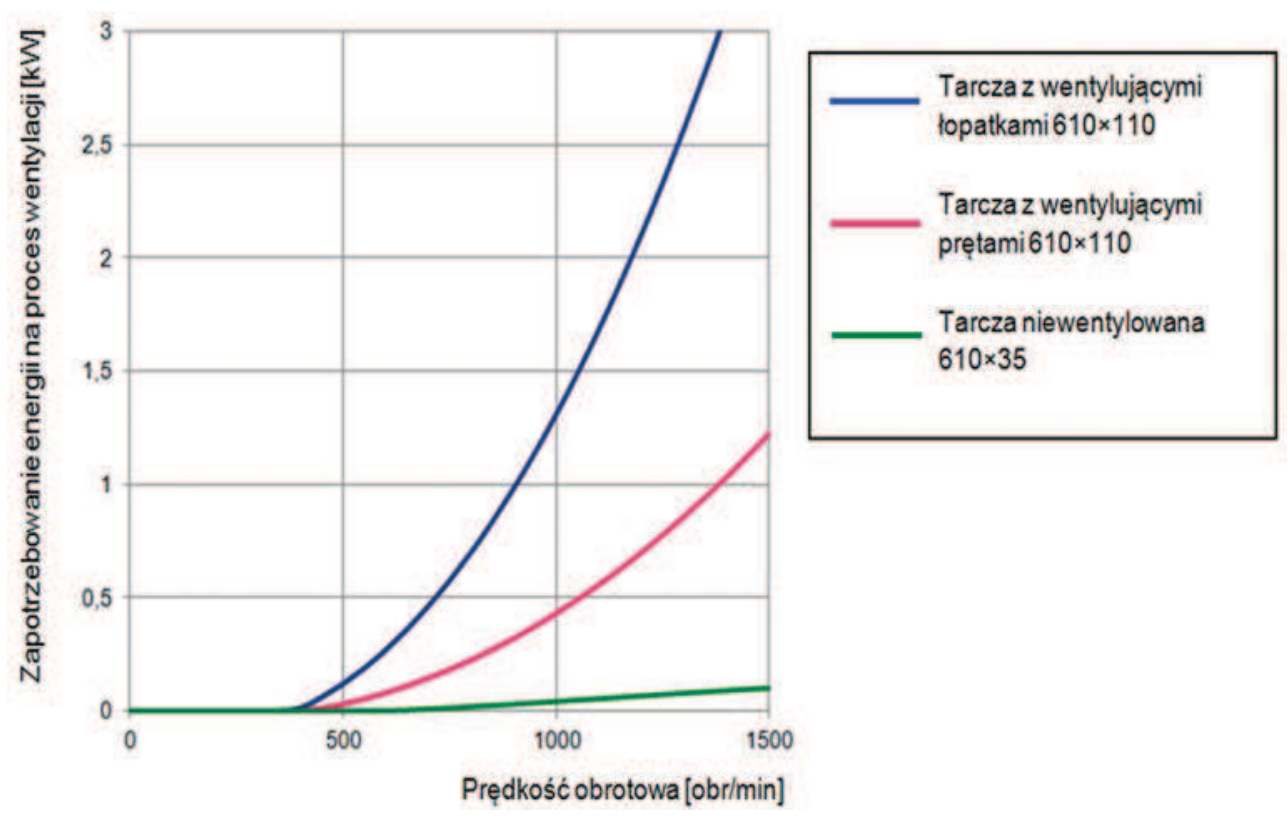

Rys. 3. Zapotrzebowanie energii na proces wentylacji tarcz hamulcowych [5].

Przy połączeniu tarczy hamulcowej z piastą stosuje się rozwiązanie firmy Knorr-Bremse przy użyciu sześciu sworzni. Tarcza o takiej konstrukcji jest stosowana zarówno w pojazdach kursujących z prędkościami 160 km/h, jak i z prędkością 200 km/h.

Badania [6] przeprowadzone na tarczy z wentylującymi prętami oraz łopatkami pokazały, że tarcza wyposażona w pręty dystansowe charakteryzuje się o 60\% mniejszym zapotrzebowaniem energii z powodu wymuszonej wentylacji w porównaniu do klasycznej tarczy z wentylującymi łopatkami. Ponadto badania te wykazały, że w tarczach z prętami wentylującymi możliwe jest uzyskanie większej o ok. 3 \% średniej mocy hamowania a przez równomierne rozłożenie prętów (mostków) na całej powierzchni tarczy intensywniej odprowadzone jest ciepło hamowania do otoczenia. Oznacza to, że w tarczy z prętami, mimo słabszego pompowania powietrza, odprowadzanie ciepła jest bardziej efektywne niż w tarczy łopatkowej. Dzięki temu tarcza z prętami jest mniej wrażliwa na powstawanie pęknięć termicznych podczas hamowania nagłego. Na rysunku 3 przedstawiono przebiegi porównawcze wartości zapotrzebowania energii na przepompowywanie powietrza przez wentylator dla tarczy z wentylującymi łopatkami, prętami i tarczy nie wentylowanej (pełnej) w funkcji prędkości obrotowej. 


\section{Sposób oszacowania uśrednionej mocy rozpraszania energii przez tarczę hamulcową rozpatrywanej jako masa w ruchu obrotowym}

W tarczach z wentylującymi łopatkami i prętami poza stratami energii na wentylatorze występują również opór bezwładności tarczy jako masy znajdującej się w ruchu obrotowym. Do wyznaczenia charakterystyki mocy pobieranej przez tarczę należy wykorzystać dane zawarte w Tab. 1. Rachunek obliczania mocy tarczy o określonej masie zaprezentowano na przykładzie tarczy typu 610×110 (średnica×Szerokość) dla jednej prędkości obrotowej.

Tabela 1. Dane wyjściowe do obliczenia oporu bezwładności tarczy hamulcowej w ruchu obrotowym.

\begin{tabular}{|l|l|l|}
\hline Lp. & Wielkości geometryczne i termodynamiczne & Oznaczenie i wartości \\
\hline 1 & Masa tarczy z wentylującymi łopatkami & $m_{f}=123,2 \mathrm{~kg}$ \\
\hline 2 & Masa tarczy z wentylującymi prętami & $\mathrm{m}_{\mathrm{p}}=112,2 \mathrm{~kg}$ \\
\hline 3 & Masa tarczy niewentylowanej & $\mathrm{m}_{\mathrm{n}}=83,4 \mathrm{~kg}$ \\
\hline 4 & Średnica zewnętrzna tarczy wentylowanej i niewentylowanej & $\mathrm{d}_{\mathrm{z}}=0,610 \mathrm{~m}$ \\
\hline 5 & Średnica wewnętrzna tarczy wentylowanej i niewentylowanej & $\mathrm{d}_{\mathrm{w}}=0,193 \mathrm{~m}$ \\
\hline 6 & Gęstość żeliwa & $\rho \dot{z}=7200 \mathrm{~kg} / \mathrm{m}^{3}$ \\
\hline 7 & Gęstość stali & $\rho \mathrm{s}=7850 \mathrm{~kg} / \mathrm{m}^{3}$ \\
\hline 8 & Przyspieszenie liniowe & $\mathrm{a}=1,0 \mathrm{~m} / \mathrm{s}^{2}$ \\
\hline 9 & Prędkość obrotowa tarczy & $\mathrm{n}=1000 \mathrm{obr} / \mathrm{min}^{3}$ \\
\hline
\end{tabular}

Objętość tarczy oblicza się z wzoru:

$$
V=\frac{m}{\rho}=\frac{123,2}{7200}=0,017\left[\mathrm{~m}^{3}\right]
$$

gdzie: $m$ - masa tarczy hamulcowej $w \mathrm{~kg}, \rho$ - gęstość materiału tarczy $w \mathrm{~kg} / \mathrm{m}^{3}$.

Grubość zastępczą roboczej, pierścieniowej części tarczy wyznacza się z zależności:

$$
g_{z}=\frac{V}{\left(\frac{\pi \cdot d_{z}{ }^{2}}{4}-\frac{\pi \cdot d_{w}{ }^{2}}{4}\right)}=\frac{0,017}{\left(\frac{3,14 \cdot 0,61^{2}}{4}-\frac{3,14 \cdot 0,193^{2}}{4}\right)}=0,064[\mathrm{~m}]
$$

Moment bezwładności roboczego pierścienia tarczy oblicza się według wzoru:

$$
I=\frac{1}{2} \cdot m\left(\frac{d_{z}^{2}}{4}+\frac{d_{w}{ }^{2}}{4}\right)=\frac{1}{2} \cdot 123,2\left(\frac{0,61^{2}}{4}+\frac{0,193^{2}}{4}\right)=6,3\left[\mathrm{~kg} \cdot \mathrm{m}^{2}\right]
$$


Prędkość kątową tarczy, przy założonej stałej prędkości obrotowej n wyznacza się z wzoru:

$$
\omega=\frac{d \varphi}{d t}=\frac{2 \cdot \pi \cdot n}{60}=\frac{2 \cdot 3,14 \cdot 1000}{60}=104,7\left[\frac{\mathrm{rad}}{\mathrm{s}}\right]
$$

Przyspieszenie kątowe tarczy, przy założeniu stałej wartości przyspieszenia pojazdu $\mathrm{a}=1 \mathrm{~m} / \mathrm{s}^{2}$, oblicza się $\mathrm{z}$ wzoru:

$$
\varepsilon=\frac{d \omega}{d t}=\frac{a}{\frac{d_{z}}{2}}=\frac{1}{\frac{0,61}{2}}=3,28\left[\frac{\mathrm{rad}}{\mathrm{s}^{2}}\right]
$$

Czas procesu hamowania można oszacować z zależności:

$$
t=\frac{\omega}{\varepsilon}=\frac{104,7}{3,28}=31,9[s]
$$

Początkową, chwilową energię kinetyczną pierścienia tarczy oblicza się z wzoru:

$$
E_{k}=\frac{I \cdot \omega^{2}}{2}=\frac{6,3 \cdot 104,7^{2}}{2}=34530,6[\mathrm{~J}]
$$

Uśredniona w czasie t moc oporu ruchu procesu hamującego wyizolowaną z pojazdu tarczę wyznacza się z wzoru:

$$
N=\frac{d E}{d t}=\frac{E_{k}}{1000 \cdot t}=1,08[\mathrm{~kW}]
$$

Jest to obliczenie jednego punktu pracy tarczy hamulcowej. Chcąc znaleźć dalsze punkty charakterystyki postępuje się w identyczny sposób podstawiając kolejne wartości prędkości obrotowej tarczy hamulcowej. Przedstawiony rachunek umożliwia obliczenie mocy zużywanej przez tarcze różnych konstrukcji przy znajomości ich masy, wymiarów geometrycznych i gęstości materiału tarczy hamulcowej przy stałym przyspieszeniem kątowym $\varepsilon$.

Na rysunku 4 przedstawiono uśredniony przebieg oporu bezwładności tarczy w ruchu obrotowym. Suma oporu bezwładności i oporu stawianego (generowanego) przez wentylator tarcz hamulcowym w ruchu obrotowym przedstawiono na rysunek 5.

Procentowy udział rozproszonej energii tarczy znajdującej się w ruchu obrotowym do energii całkowitej układu badanego przedstawia rysunek 6. 


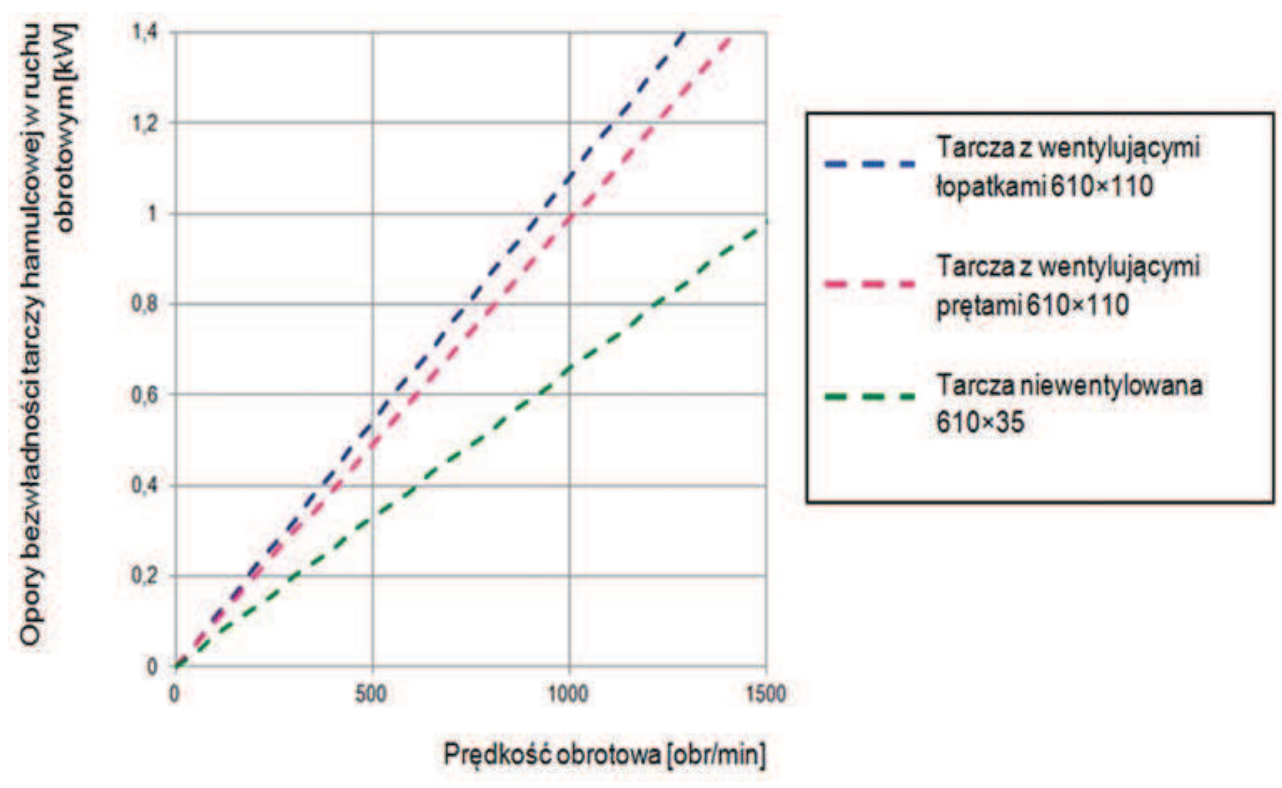

Rys. 4. Przebiegi uśrednionych wartości mocy oporów ruchu tarczy hamulcowej w ruchu obrotowym, w funkcji prędkości tego ruchu.

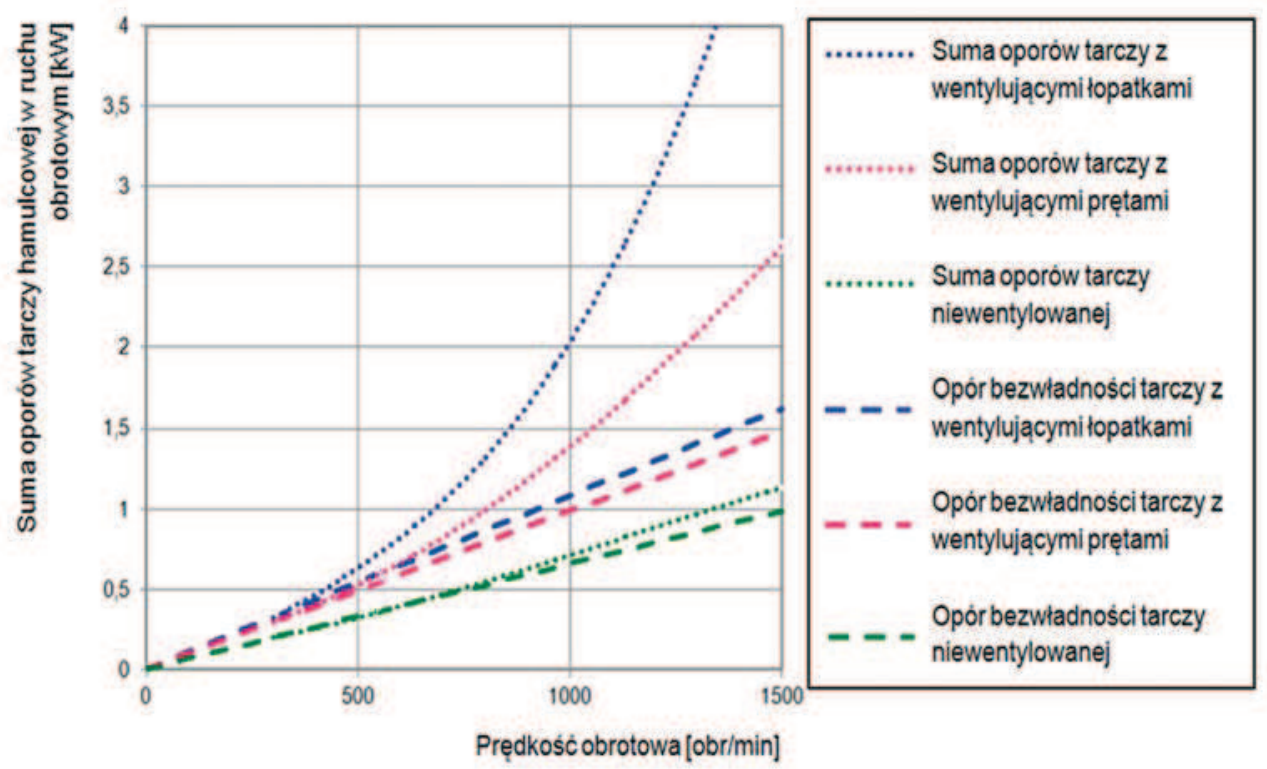

Rys. 5. Suma oporów tarczy hamulcowej w ruchu obrotowym (opór bezwładności i opór generowany przez wentylator tarczy). 


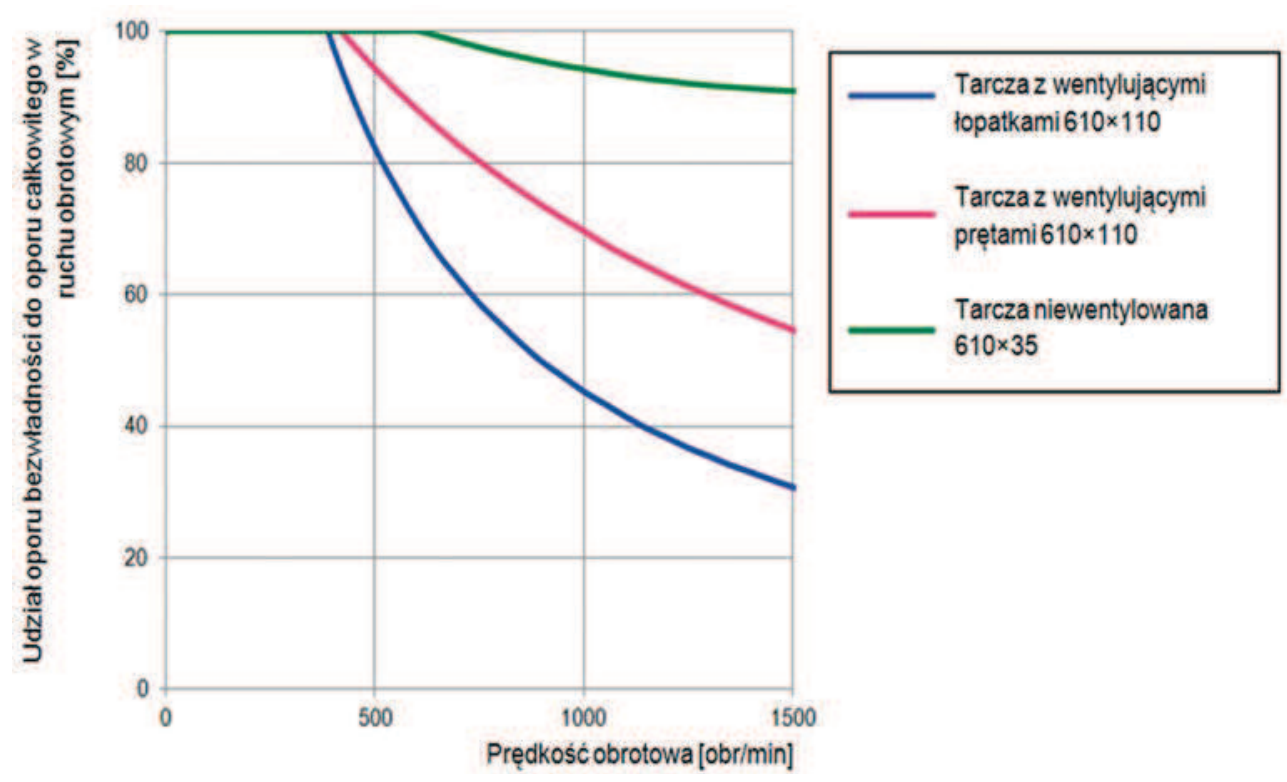

Rys. 6. Procentowy udział oporu bezwładności tarcz hamulcowych do oporu całkowitego (opór bezwładności i opór generowany przez tarczę hamulcową).

\section{Badanie tarczowego hamulca kolejowego przy zamkniętych kanałach wentylacyjnych tarczy hamulcowej}

\subsection{Metodyka i obiekt badań}

Badania przeprowadzone zostały na bezwładnościowym stanowisku do badań hamulców pojazdów szynowych, obiektem badań była tarcza hamulcowa typu 610×110 z wentylującymi łopatkami oraz komplet dotartych okładzin typu 200 FR2OH.2 o grubości 35 mm. Do badań wykorzystany został program badawczy C (szybka jazda) zgodnie z [1], hamowania wykonano z prędkości 120, 160, 200 km/h, przy nacisku okładziny do tarczy wynoszącym 44 kN i masie hamującej przypadającej na jedną tarczę 7,5 t. Do rejestracji temperatury tarczy w całym zakresie czasu hamowania wykorzystano sześć termopar zamocowanych po trzy z dwóch stron tarczy i rozmieszczone co $120^{\circ}$ na trzech promieniach. Zatrzymanie procesu "pompowania" powietrza poprzez ew. obecnością obcych ciał we wszystkich przestrzeniach międzyłopatkowych, uzyskano przez założenie opaski zaciskowej na łopatkach wentylacyjnych. Sposób zasłonięcia przestrzeni wentylacyjnej przedstawiono na rysunku 7. 


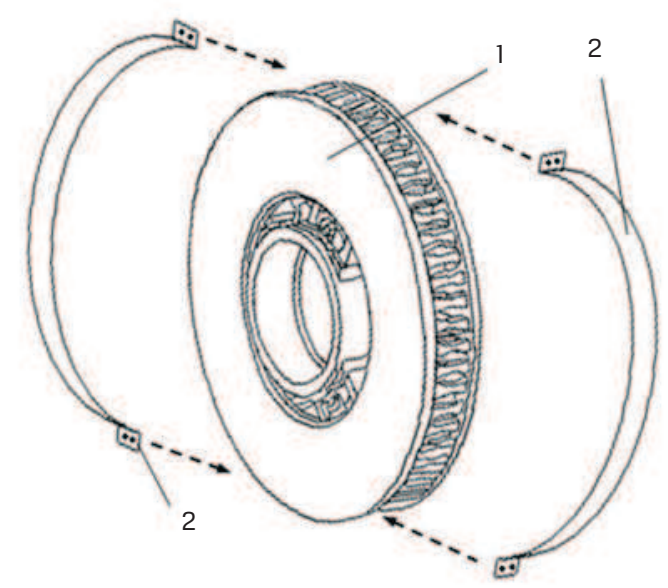

Rys. 7. Montaż opaski zaciskowej na tarczy hamulcowej typu 610×110: 1-tarcza hamulcowa, 2- część prawa i lewa opaski zaciskowej.

Przed rozpoczęciem badań zasadniczych, wykonano serię badań identyfikacyjnych na tarczy z otwartymi kanałami wentylacyjnymi, dzięki czemu realizowany był niezakłócony przepływ powietrza chłodzącego. Dla każdej prędkości początku hamowania wykonano osiem powtórzeń hamowań.

\subsection{Analiza wyników badań}

Podczas badań wielkościami mierzonymi była temperatura tarczy mierzona w chwili zatrzymania (rys. 8), średni współczynnik tarcia (rys. 9) oraz czas stygnięcia tarczy do temperatury $60^{\circ} \mathrm{C}$ (rys. 10). Chłodzenie tarczy realizowano symulując przejazd wagonu z prędkości $100 \mathrm{~km} / \mathrm{h}$.

Hamowania tarczy z zasłoniętymi łopatkami wentylacyjnymi mogły doprowadzić do zmian w strukturze materiału w wyniku silnego obciążenia cieplnego. Na powierzchni ciernej tarczy pojawiły się przegrzania w postaci dwóch pierścieni w okolicach średnicy wewnętrznej i średnicy zewnętrznej tarczy. Przebarwienia powierzchni ciernej zaobserwowano już po wykonaniu sześciu hamowań (rys. 11).

Podczas hamowań na tarczy z zasłoniętą przestrzenią łopatkową rejestrowano na jednej z termopar przekroczenie chwilowej temperatury tarczy powyżej $400^{\circ} \mathrm{C}$ osiągającą wartości w przedziale $404 \div 417^{\circ} \mathrm{C}$. Zgodnie z [1] tarcze hamulcowe pojazdów szynowych w czasie hamowań nie powinny osiągać chwilowej temperatury ponad $400^{\circ} \mathrm{C}$, ponieważ jest to powodem odkształcenia tarczy i utraty wymaganej wytrzymałości i plastyczności. 


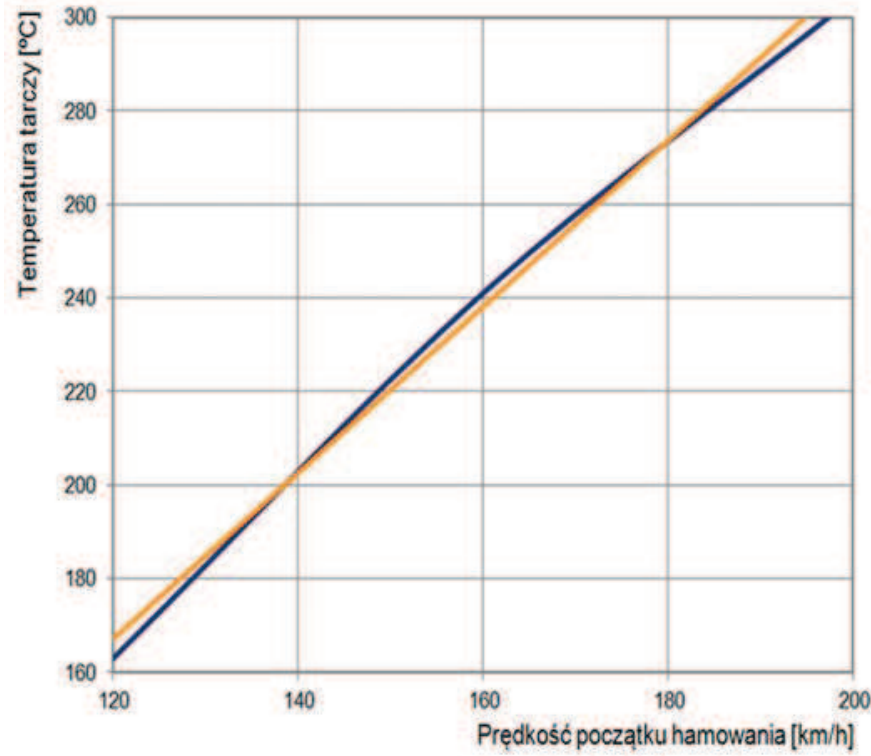

Tarcza zasionięta

Tarcza wentylowana

Rys. 8. Rozkład średniej temperatury tarczy hamulcowej typu 610×110.
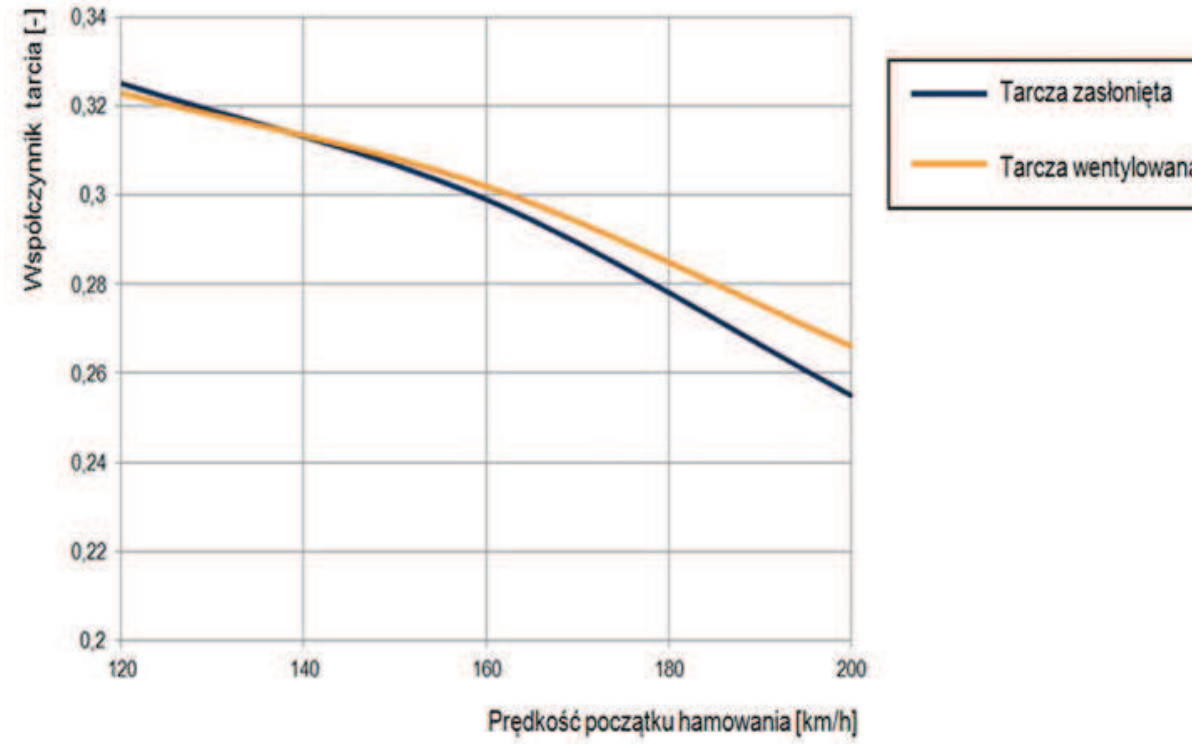

Rys. 9. Przebieg średniego współczynnika tarcia 

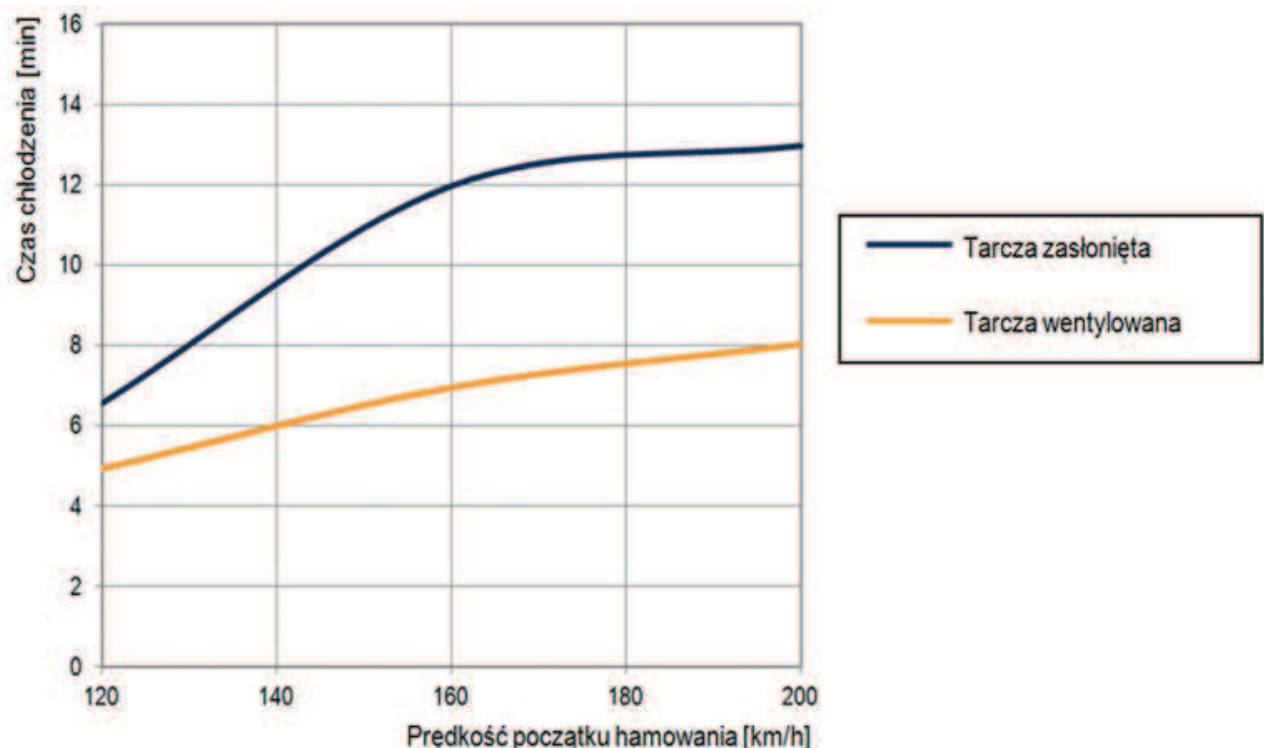

Rys. 10. Przebieg czasu chłodzenia tarczy w czasie symulowanej jazdy wagonu ze stałą prędkościa $120 \mathrm{~km} / \mathrm{h}$ (prędkość obrotowa tarczy 600obr/min).

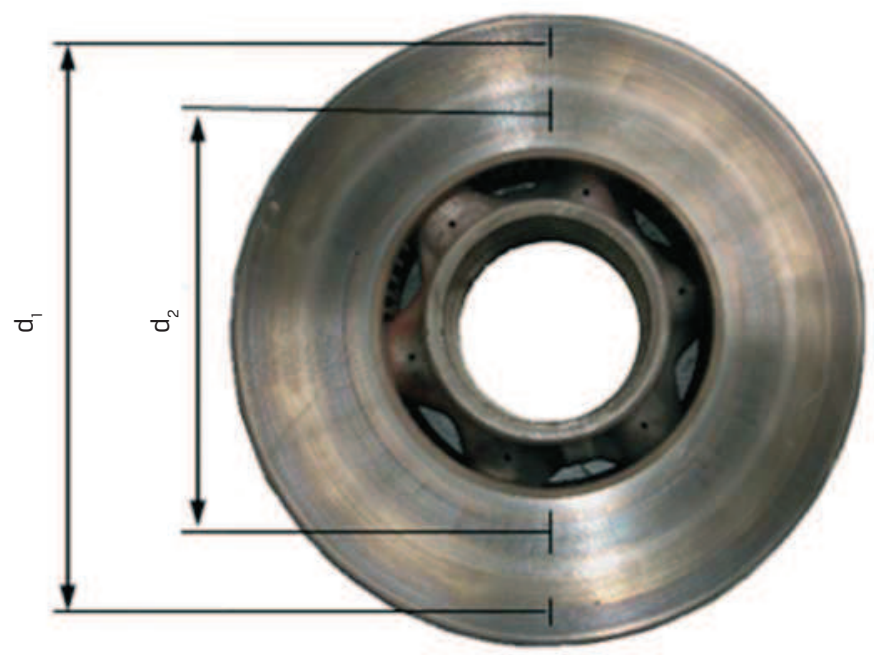

Rys. 11. Widok tarczy po serii hamowań z zasłoniętymi łopatkami wentylacyjnymi z widocznym przegrzaniem powierzchni w postaci dwóch pierścieni o różnych średnicach. 


\section{Podsumowanie}

W artykule przedstawiono dwa aspekty związane z eksploatacją kolejowego hamulca tarczowego: pierwszy dotyczący energii rozpraszanej przez wentylator tarcz hamulcowych, drugi aspekt związany z wpływem ew. istniejących/nieistniejących kanałów wentylacyjnych na proces hamowania.

Przedstawiony w artykule rachunek umożliwia oszacowanie uśrednionej mocy oporu bezwładności tarczy w ruchu obrotowym. Dzięki temu możliwe jest rozgraniczenie całkowitego oporu tarczy na opór bezwładności masy tarczy w ruchu obrotowym i opór stawiany przez wentylator tarczy podczas pompowania powietrza do procesu chłodzenia tarczy.

Analizując wykres przedstawiony na rysunku 4 stwierdza się, iż mimo tego samego rozmiaru tarcz (610×110), tarcza prętowa powoduje o 9\% mniejszy opór bezwładności niż tarcza łopatkowa w całym zakresie prędkości obrotowej.

Największy udział oporu bezwładności masy tarczy w ruchu obrotowym występuje przy prędkości do $450 \mathrm{obr} / \mathrm{min}$ dla tarcz wentylowanych i do $600 \mathrm{obr} / \mathrm{min}$ dla tarcz pełnych. Dalszy wzrost prędkości obrotowej powoduje, że wzrastają straty na wentylatorze tarcz. Udział strat z tytułu obrotu tarczy o określonej masie względem strat całkowitych zmniejsza się od 100\% do 30\% dla tarczy z wentylującymi łopatkami i od 100\% do 54\% dla tarczy z wentylującymi prętami. W tarczach pełnych straty masowe stanowią od $90 \div 100 \%$ całkowitych strat w zależności od prędkości obrotowej.

Po przeprowadzeniu badań stanowiskowych [5] stwierdzono, że zasłonięcie przestrzeni łopatkowej symulujące obecność ciał obcych między łopatkami, nie ma istotnego wpływu na zmiany wartości temperatury zmierzonej w chwili zatrzymania oraz na wartość współczynnika tarcia w odniesieniu do tarczy z niezakłóconą wentylacją. Zaobserwowane zmiany temperatury oraz współczynnika tarcia mieszczą się w granicach błędu statystycznego. Brak obserwacji zmiany temperatury tarczy przy otwartej i zamkniętej przestrzeni łopatkowej może wynikać z długich czasów wymiany ciepła hamowania do otoczenia w stosunku do czasu trwania pojedynczego hamowania, co zostało opisane w [3].

Natomiast zasłonięcie przestrzeni łopatkowej wpływa znacząco na wydłużenie czasu chłodzenia tarczy po hamowaniu. Tarcza wentylowana w czasie jazdy wagonu z symulowaną prędkością $100 \mathrm{~km} / \mathrm{h}$ chłodzi się o $25 \div 40 \%$ szybciej niż tarcza zasłonięta w zależności od prędkości początku hamowania. 


\section{Literatura}

[1] Kodeks UIC. Hamulec - Hamulec tarczowy i jego zastosowanie. Warunki dopuszczenia okładzin hamulcowych. Wydanie 6, listopad 2006.

[2] Rail Consult Gesellschaft für Verkehrsberatung mbH. Wagon osobowy Z1 02, układ jezdny-tom2. Dokumentacja Techniczno-Ruchowa.

[3] SOROCHTE], M.: Kształtowanie jakości zespołu ciernego hamulca tarczowego. Przegląd Kolejowy 1/94.

[4] SAWCZUK, W., Zastosowanie płytek bimetalu w kolejowej tarczy hamulcowej z wentylującymi łopatkami, XXVII Seminarium Kół Naukowych „Mechaników”, Warszawa 24-25 kwietnia 2008r., s. 229.

[5] SAWCZUK, W., SZYMAŃSK,I M. G.: The Research on Railway Disc Brake with Closed Ventilation Canals of the Brake Disc, Proc of $8^{\text {th }}$ European Conference of Young Research and Science Workers in Transport and Telecommunications TRANSCOM 2009, 22-24 June 2009, ss. 259-262.

[6] SIEMENS, G.: Auslegung und Leistungsgrenzen von Scheibenbremsen. „ZEV-Glas. Ann”. 112 (1988), nr. 4 April, Ss. 139-143. 